\title{
確率統計的地震入力に基づく免震系の基本応答特性之 最適パラメーター \\ FUNDAMENTAL DYNAMIC RESPONSE CHARACTERISTICS AND OPTIMUM PARAMETERS OF BASE ISOLATED STRUCTUERS BASED ON NONWHITE RANDOM PROCESS
}

\author{
浅野幸一郎*, 平 松 昌子** \\ Koichiro ASANO and Masako HIRAMATSU
}

\begin{abstract}
The purpose of this study is to develop an analytical approach to the estimation of random response of the multi-story base isolated structure with the viscous damping and the hysteretic damping characteristics. The stochastic second order moment of an earthquake response of the multi-story base isolated structure are obtained by solving a simple simultaneous first order algebraic equation. The optimum damping characterisitics of the base isolation system are determined by the solution of extreme value problem for the objective function defined as the combination of the stochastic earthquake response of the superstructure.
\end{abstract}

Keywords : optimum viscous damping, optimum hysteretic damping, stochastic second order moment response, multi-story base isolated structure

最適粘性減衰, 最適履歴減衰, 統計的 2 次モーメント応答, 多質点免震構造物

\section{1. 序}

地震国日本の建築構造として, 耐震構造に代わり注目 されている免震あるいは制震構造のうち前者について は，試作の段階から実用の段階に入りつつある。しかし ながら，免震層を構成するアイソレーターまたはダン パー（以下，免震機構）については，地震入力のランダ 么性に伴い見込まれる変形または耐力上の余裕は別とし て，それらの適性度については問われていないようであ る。つまり免震構造が下部構造を形成するとき，それが 上部構造の最適耐震安全性につながるのかどうかが問題 となるはずである。本論のねらいは，この点について基 礎的な検討を加えるために, 確率統計的地震応答に基づ いた解析手法を開発し，その数值解析例を免震系の基本 応答特性とともに示すことにある。

このねらいに沿って, 地震入力として筆者らが建築架 構の地震信頼性の検討のために用意したモデル，すなわ 与表層地盤の地動加速度波形の最大振幅, 卓越振動数之 スペクトルの形状係数により規定される非定常ノン・ホ ワイトランダム過程を，本論では定常のそれとして採用
する。定常入力を採用するのは, 系の広範なパラメトリッ クサーベイに適しているからに他ならない。

ところが, 定常入力を前提としても，一般に多自由度 系の確率系統計的地震応答を求めることは必ずしも容易 ではなく，例えば，伝達関数の実部の振動数に関する無 限積分評価などの煩雑な手法によらねばならない。しか し本論では, 既報の非定常過程を対象とする微分方程式 の解を時間軸上で求める代わりに，定常過程を前提とし た既報”で開発した手法一簡単な連立 1 次方程式の解と してそれを求めている。

免震機構の最適性については，それを規定する動的パ ラメータを変数とし, 上部構造の確率統計的地震応答ま たはそれらの線形結合を目的関数とする極値問題の解と して与えられる。

\section{2. 解析手法}

\section{1 免震機構のモデル化}

一般にアイソレーターとダンパーで構成される免震機 構は, 1 階基礎梁と基礎との間に設置される。アイソレー
* 関西大学工学部建築学科 ·教授 $\cdot$ 博士 (工学)

** 関西大学工学部建築学科 大学院生 ·修士 (工学)
Prof., Dept. of Architecture, Faculty of Engineering Kansai Uniy., Dr. Eng.

Graduate Student, Dept. of Architecture, Faculty of Engineering Kansai Univ., M. Eng. 
ターは建築物と地盤とを振動的に絶縁する機構であり， 鉛直方向に比べ水平方向の剛性が極めて低い支承により 上部構造物を支持し, 構造物全体の長周期化を計るため の装置である。一方，ダンパーはアイソレーターが水平 方向に過大変形することを抑制し, 入力エネルギーを吸 収するための装置である。ダンパーは作動原理の観点か ら，(1)速度依存型の粘性抵抗を利用する粘弾性ダンパー と, (2)履歴特性をもち履歴消費エネルギーを利用する履 歴ダンパーなどに分類できる2〉。本論の解析に用いる免 震機構としては,これらの点を考慮にいれて, (1)粘弾性 免震機構と(2)免震層の挙動が Positive-Deficiency 特 性 ${ }^{3)}$ (以下簡単のため p.d. 特性と記す)，で表される履 歴特性に従う粘塑性免震機構を設定する。この履歴特性 は, 地震時の系の挙動が強い塑性域にまで至る灾答性状 の定性的傾向を十分に把握できるであろうこと到を考慮 し, 問題の簡略化のために採用している。

2.2 統計的等価線形化法

履歴特性を持つ系のランダム応答の評価のために, 本 論で取り扱う p.d. 特性 (図一-1) は, 統計的等価線形 化法により以下のように線形化される。

p. d. 特性 $\phi$ は，次式により表される。

$$
\phi(x, \dot{x} ; \delta)=r x+(1-r) \delta \operatorname{sgn}(\dot{x})
$$

(1) 式中, $x, \dot{x}, r$ および $\delta$ は, それぞれ, 系の変位, 速度, 塑性分枝勾配および Bi-Linear 形復元力特性の 弾性限変位に対応する変位パラメータを表している。ま た, $\operatorname{sgn}(*)$ は符号関数を表し, 確率統計的手法に基 ゔく応答解析を行うために，この符号関数に等価線形化 法を適用すると, $E[*]$ を平均演算子とし, $\dot{x}$ の正規 性を仮定して，

$$
\operatorname{sgn}(\dot{x}) \cong E\left[\frac{\partial}{\partial \dot{x}}\{\operatorname{sgn}(\dot{x})\}\right] \dot{x} \cong \sqrt{\frac{2}{\pi}} \frac{\dot{x}}{\sigma_{\dot{x}}} \cdots
$$

となる。ここで $\sigma_{\dot{x}}$ は $\dot{x}$ の標準偏差応答を示す。

式に（2）式を代入すれば,

$$
\phi(x, \dot{x} ; \delta)=r x+(1-r) \delta \sqrt{\frac{2}{\pi}} \frac{\dot{x}}{\sigma_{\dot{x}}} .
$$

となる。

\section{3 統計的 2 次モーメント応答の常微分方程式の誘導} 一般に, 入力地動加速度 $f$ を受ける多質点線形構造 物の基礎運動方程式は,

$$
[m]\{\ddot{x}\}+[c]|\dot{x}|+[k]\{x\}=-[m]\{1\} f
$$

となる。ここで $\{x\},\{\dot{x} \mid$ および $\{\ddot{x}\}$ はそれぞれ相対変位応 答ベクトル, 相対速度応答ベクトル, および相対加速度 応答ベクトル， $[m],[c]$ おび $[k]$ は，それぞれ質量マ トリックス，線形粘性減衰係数マトリックス，および剛 性マトリックスを示す。ここで・, ・はそれぞれ時間に 関する 1 階, 2 階微分を表す。相対座標系の運動方程式 を層間座標系の運動方程式に変換すると，（4）式は,

$$
-\frac{d}{d t} u_{i}=\sum_{j=1}^{2 n} a_{i j} u_{j}+b_{i} f
$$

と表される。ここで， $u_{i}$ は層間変位応答 $(i=1 \sim n)$ お よび層間速度応答 $(i=n+1 \sim 2 n)$ を表し, $n$ は層数, $a_{i j}$ は系の粘性娍衰と剛性を含むマトリックスの要素で ある。 $f$ は基盤にホワイトノイズ過程 $\ddot{w}$ を受ける表層 の絶対加速度応答であって, 加速度波形関数の卓越振動 数 $\omega_{g}$ とスペクトルの山の鋭さを規定する形状係数 $h_{g}$ で規定され，次式で与えられる4。

$$
f=\ddot{z}+\ddot{w}=-\left(2 h_{g} \omega_{g} \dot{z}+\omega_{g}^{2} z\right)
$$

ここで, $z, \dot{z}$ は表層地盤の相対変位と相対速度応答で ある。（6）式で与えられる $f$ の定常パワースペクトル 密度は, $f$ の 2 乗平均値を $\sigma_{f}^{2}$ として次式で与えられる。

$$
S_{f}(\omega)=\frac{4 h_{g}}{\left(1+4 h_{g}^{2}\right) \omega_{g}} \cdot \frac{\omega_{g}^{4}+4 h_{g}^{2} \omega_{g}^{2} \omega^{2}}{\left(\omega_{g}^{2}-\omega^{2}\right)^{2}+4 h_{g}^{2} \omega_{g}^{2} \omega^{2}} \sigma_{f}^{2}
$$

さて，(5) 式を規定する状態変数 $u_{i}(i=1 \sim 2 n)$ に 加えて，新たに $z, \dot{z}$ を状態変数 $u_{2 n+1}=z, u_{2 n+2}=\dot{z}$ と して, それらの積 $u_{i} \times u_{j}$ を時間 $t$ で微分し, $E\left[u_{i} u_{j}\right]$ $=m_{i j}$ と表記すれば, $m_{i j}$ に関する常微分方程式は, $(5)$ 式（6）式より,

$$
\dot{m}_{i j}=\sum_{l=1}^{\widetilde{n}}\left(a_{i l} m_{l j}+a_{j l} m_{l i}\right)+b_{i} E\left[\ddot{w} u_{j}\right]+b_{j} E\left[\ddot{w} u_{i}\right]
$$

となる”。ここで， $\tilde{n}=2 n+2$ を示す。また（6）式よ り，ノンホワイトランダム過程 $f$ の振幅包絡線関数が, 2 乗平均の形, すなわち,

$$
\sigma_{f}^{2}=4 h_{g}^{2} \omega_{g}^{2} m_{\widetilde{n} \tilde{n}}+4 h_{g} \omega_{g}^{3} m_{\widetilde{n}-1 \widetilde{n}}+\omega_{g}^{4} m_{\widetilde{n}-1 \widetilde{n}-1}
$$

と表現される。( 8$)$ 式中, $E\left[\ddot{w} u_{i}, E\left[\ddot{w} u_{j}\right]\right.$ は, $u_{i}$ ま たは $u_{j}$ が $\dot{z}$ とならない場合 $(i, j \neq \tilde{n})$ ，恒等的に零と なり， $u_{i}$ または $u_{j}$ が $\dot{z}$ となる場合 $(i, j=\tilde{n}),(9)$ 式を用いて， $m_{\widetilde{n} \tilde{n}}$ を算出すれば，ノンホワイトランダ 么過程を地震入力とする系となる。本論では，広範囲な パラメトリックサーベイをも実施する関係から，まず， 定常応答過程を解析対象とする。すなわち, $\dot{m}_{i j}=0$ とし, $m_{i j}=M_{1}$ 亡表記すれば，（8）式は,

$$
[A] \mid M\}=\{B\}
$$

のごとく書き換えられ, 統計的 2 次モーメント応答に関 する簡単な連立線形代数方程式が得られる"。こで, $[A]$ は地震入力と系の粘性および剛性を含む（8）式の [a]をもとに拡張されたマトリックス， $\{B\}$ は地震入力の 卓越振動数 $\omega_{g}$ とスペクトルの山の鋭さを規定する形状 係数 $h_{g}$ および振幅包絡線関数による非斉次べクトルで あり, 次節の『数值解析例とその結果」で, その要素に ついて説明する。一方, 入力地動加速度 $f$ を受ける免 震層の履歴特性を p.d. 特性とする多質点非線形構造物 の等価線形化法をほどこした基礎運動方程式は, 


$$
[m]\{\ddot{x}\}+\left[c^{\prime}\right]\{\dot{x}\}+\left[k^{\prime}\right]\{x\}=-[m]\{1\} f
$$

となる。ここで, この場合の統計 2 次モーメント応答の ための連立方程式の誘導過程は, 多質点線形構造物の運 動方程式 (4). 式を統計 2 次モーメント応答に関する連 立線形代数方程式（10）式に置換する場合と基本的に異 ならない。しかし，(11）式では免震層の履歴特性に p.d. 特性を用いるために（（3）式に示される等価線形 化された履歴特性の影響により，線形粘性減衰マトリッ クス $\left[c^{\prime}\right]$ は, $(4)$ 式の $[c]$ にある免震層に関する項に, 非線形要素が組み込まれ，また剛性マトリックス $\left[k^{\prime}\right]$ は，（4）式の $[k]$ の内，免震層に関する剛性 $k_{1}$ を $r k_{1}$ に変換し得られる。

\section{4 最大変位応答の近似評価}

最大変位応答の近似評価については，非定常過程の場 合について示している5!。ここではそれを定常過程に拡 張した場合を示す。

微少な時間 $[d t]$ 間に非定常变位応答が閾値レベル $\lambda_{i}$ を超過する確率分布をPoisson 分布とし, 変位と速度 応答の同時確率分布を 2 次元の Gaussian 分布に近似で きるものとする。継続時間 $t_{d}$ 中に, $u_{i}(t)$ が閾値レベル $\lambda_{i}$ を超過する確率 $p_{i}\left(t_{d}\right)$ は正負の両勾配を考慮し，また， $\lambda_{i}$ が最大値であるとすれば, 本論の応答の定常性の仮 定より,

$$
\lambda_{i}=\sigma_{u_{i}} \sqrt{2 \log _{e}\left(\frac{t_{d} \sigma_{\dot{u}_{i}}}{\pi \sigma_{u_{i}}}\right)}
$$

となり，これが，定常過程での $i$ 層の近似的な最大変位 応答となる。ここで， $\sigma_{u_{i}}, \sigma_{\mathfrak{u}_{i}}$ はそれぞれ $i$ 層の層間変 位応答および層間速度応答の標準偏差応答である。

2.5 免震機構の最適動力学パラメーターの推定

本論では, 免震機構の粘性減衰や履歴減衰に依存する 上部構造物の 2 次モーメント応答を目的関数 $J$ とすると,

$$
|J|=\left\{M \mid=[A]^{-1}\{B\}\right.
$$

一方, 免震機構を規定する動力学パラメーター（以下制

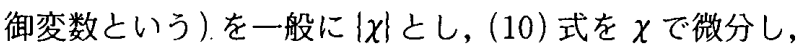

$$
\frac{\partial A}{\partial \chi}\{M\}+[A]\left\{\frac{\partial}{\partial \chi} M\right\}=\{0\} \text {. }
$$

が得られる。したがって，(13）式より,

$$
\left\{\frac{\partial M}{\partial \chi}\right\}=[c]\{B\}
$$

ただし

$$
[c]=-[A]^{-1}\left[\frac{\partial A}{\partial \chi}\right][A]^{-1}
$$

が得られる。したがって, $\frac{\partial J}{\partial \chi}=0$ で目的関数 $J$ は極値 を持ち,この時の $\chi$ が上部構造物の応答が最小となる ような免震機構を規定する最適動力学特性值となる。

\section{3. 数值解析例とその結果}

\section{1. 解析対象構造物モデル}

上部構造物の忘答は, 免震機構を取り付けることによ り抑制され，その振動は弾性領域にとどまることが一般 に期待される。また，地震入力を受ける上部構造物は基 本モードによる振動が支配的であり，上部の多質点構造 物は, 1 質点弾性構造物に置換することが可能であるう。 本論では, 解析対象構造物モデルは, 図一 2 に示すよう な粘弾性免震機構を取り付けた免震建物と粘塑性免震機 構を取り付けたものとする。これらのモデルに対する， 2.3 節の $[a]$ マトリックスは, 粘弾性免震建物に関して は,

$$
[a]=\left[\begin{array}{cccccc}
0 & 0 & 1 & 0 & 0 & 0 \\
0 & 0 & 0 & 1 & 0 & 0 \\
-\omega_{d}^{2} & \mu \omega^{2} & -2 h_{d} \omega_{d} & 2 \mu h \omega & \omega_{g}^{2} & 2 h_{g} \omega_{g} \\
\omega_{d}^{2} & -(1+\mu) \omega^{2} & 2 h_{d} \omega_{d} & -2(1+\mu) h \omega & 0 & 0 \\
0 & 0 & 0 & 0 & 0 & 1 \\
0 & 0 & 0 & 0 & -\omega_{g}^{2} & -2 h_{g} \omega_{g}
\end{array}\right]
$$

粘塑性免震建物に関しては,

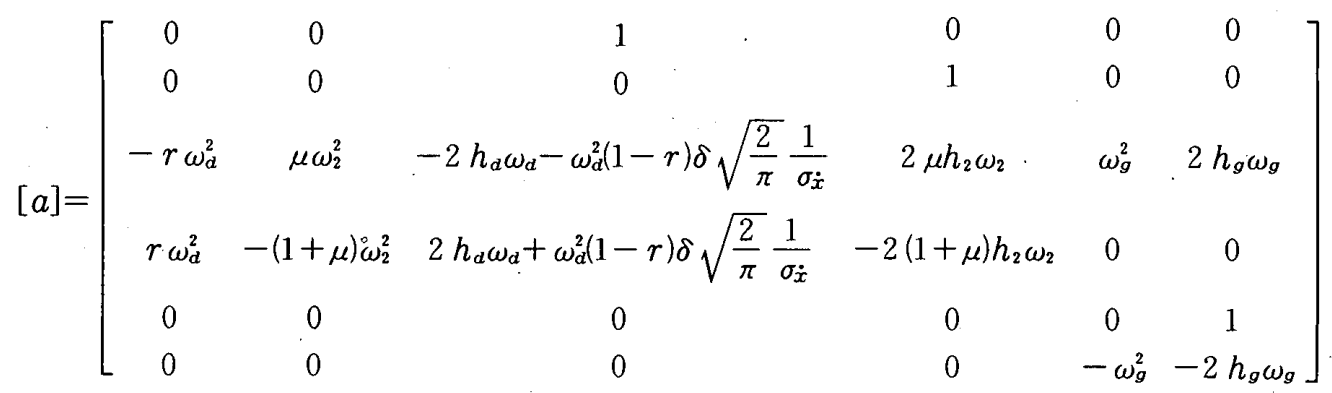

となる。(17)，(18）式中 $\omega_{d} ， \omega$ はそれぞれ免震層と上 部構造物の固有角振動数， $h_{d}, h$ はそれぞれ免震層と上
部構造物の非連成線形粘性臨界減衰比, $h_{g}, \omega_{g}$ は入力 スペクトルのピークの鋭さを示す形状係数と卓越振動数 


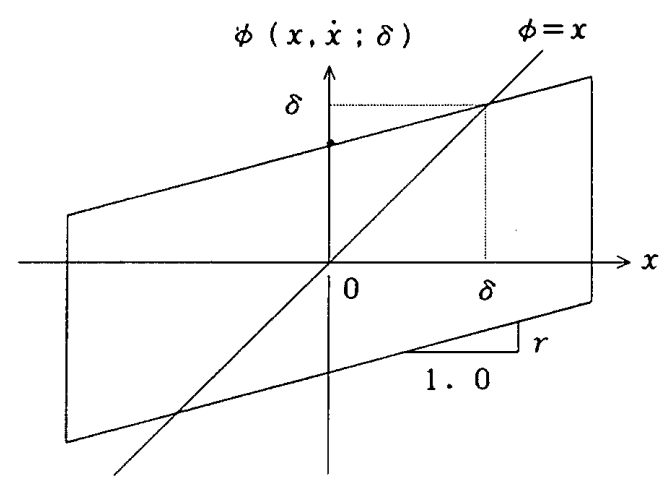

図一1 p-d. 特性

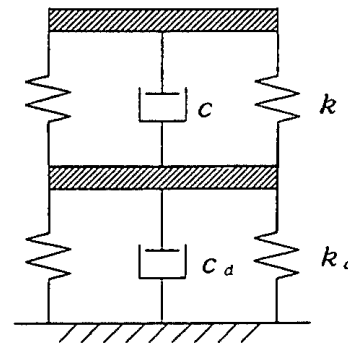

（a）粘弾性免震系

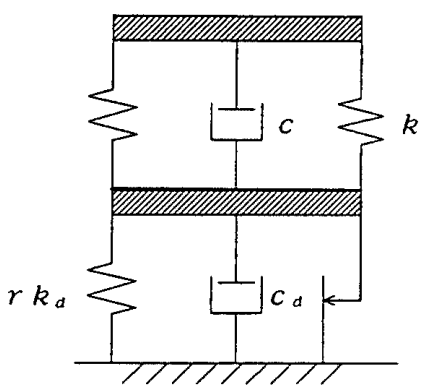

(b) 粘塑性免霞系
図一2 解析対象構造物モデル

を示す。ここでは，免震建物の基本固有周期 $\left(T_{t}\right)$ を 3.0 秒, 上部構造物の固有周期 $(T)$ 亡臨界減衰比 $(h)$ を 0.3 秒と 0.05 , 入力地震動のスペクトルの形状係数 $\left(h_{g}\right)$ を 0.5 , 卓越振動数 $\left(f_{g}=\frac{\omega_{g}}{2 \pi}\right)$ を $3.0 \mathrm{~Hz}$, 最大入力地動加 速度振幅（ $f_{\max }$ : 本論では近似的に $3 \sigma_{f}$ として与えてい る）を粘弾性免震系では $200 \mathrm{gal}$, 粘塑性免震系では $400 \mathrm{gal}$ を標準パラメーターとする。これらの值は, 各々, 建物の挙動をおおむね弾性領域にとどめるべきレベル と，人命への重大な損害を回避すべきレベルに対応して いる。

\section{2 粘弾性免震系}

図一3 は, 図一2(a) に示す粘弾性免震構造物モデル に対する統計的 2 次モーメント応答を (10) 式により求 め, $h_{d}=0.01 \sim 1.0$ に対して上部構造物と免震層の最大 層間変位応答が $f_{g}$ をパラメーターに選び描かれている。 この図から $f_{g}$ が増加するにつれて, 免震層の臨界減衰 比に対する系の応答量は鋭敏に娍少することが分かる。 このことより， $f_{g}$ が大きな場合の方が系の最大層間変 位応答は抑えられ，したがって，入力地震動のスペクト ルの卓越振動数が高い地盤, 一般に, 硬質性地盤では, 免震効果が大きいことが期待される。また， $h_{d}=0.01$ ー 1.0 の範囲で上部構造物の応答が最小となる最適臨界 減衰比 $\left(h_{o p t}\right)$ が存在することがわかる。さらに, 同図よ り, $h_{d}$ が 0.4 以上で上部構造物の最大層間変位応答は, $h_{d}$ に対して余り変化しなくなり,ほぼ一定の值となる。

免震系の最適動力学パラメーター $\left(h_{\text {opt }}\right)$ およびこれに
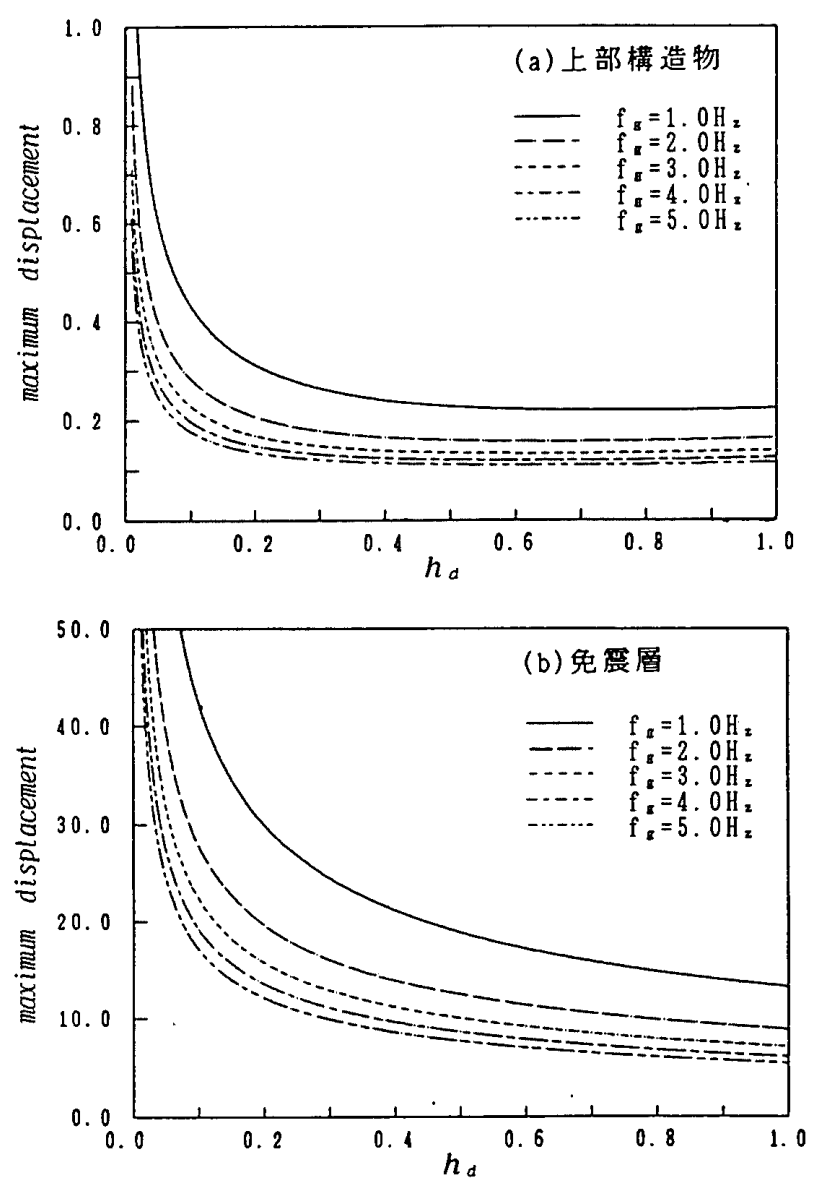

図一3 免震層の臨界減衰比に対する最大層間変位応答（粘弾性 免震系)

対応する上部構造物および免震層の応答と系の特性との 関係を明確に示すために，図一 4 には，2.5 節 (15) 式 の制御変数に関する偏微分が零となる，すなわち，上部 構造物の統計的 2 次モーメント応答が最小となる $h_{\text {opt }}$ および上部構造物と免震層の 2 次モーメント応答が， $f_{g}$ に対して $T_{t}$ をパラメータに選び描かれている。同図 (a) では，卓越振動数が大きくなるにしたがって， $h_{\text {opt }}$ は 0.9 に収束し, 同図 (b) より，上部構造物の応答が低 娍され，免震効果が顕著に現れており，また，同図 (c) では, $f_{g}<1$ で免震層の応答は最大値を持ち， $f_{g} \geqq 1$ で は応答は減少する傾向がある。このことは, 免震構造物 の基本固有周期 (3 秒) 付近で共振現象が起きているこ とによると考えられる。

\section{3 粘塑性免震系}

図一2(b) に示す粘塑性免震構造物モデルに対する 2 次モーメント応答を求めた結果のうちから, 最大変位応 答が, 図一 5 は $f_{\max }$, 図一6 は $f_{g}$ をパラメーターとし, 免震層の降伏加速度比 $q$ ( $f_{\max }$ に対する系の降伏加速 度の比）に対して描かれている。図一 5 から， $f_{\max }$ にか かわらず, 上部構造物の最大変位応答が最小となる最適 值 $\left(q_{\text {opt }}\right)$ は, 約 0.1 となり， $q$ が $0.05 \sim 0.5$ の範囲で最 適值が必ず存在することが分かる。 $q_{\text {opt }}$ (ここでは，降 

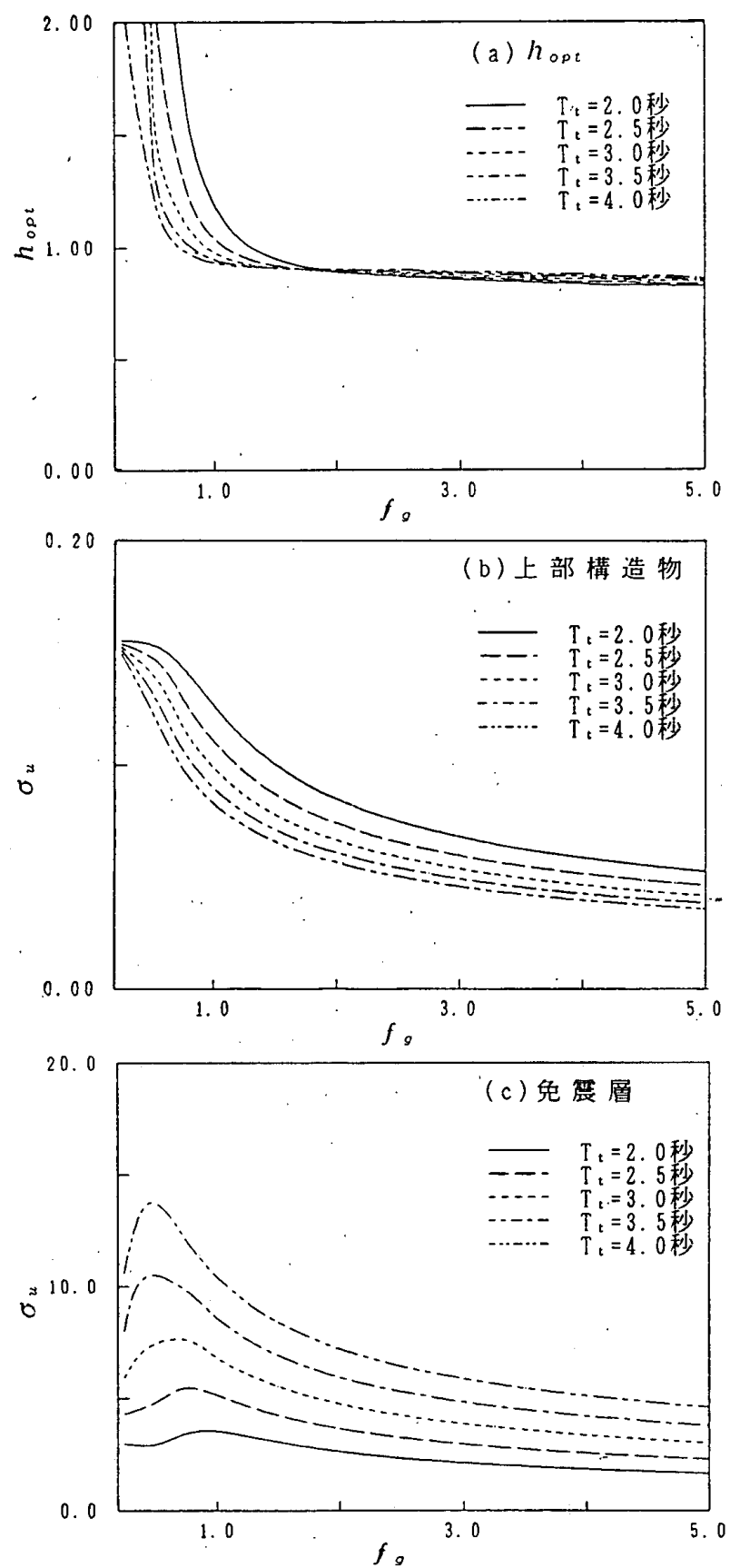

図一4上部構造物の統計的 2 次モーメント応答が最小となる地 震動の卓越振動数に対する各種応答

伏加速度比が 0.1）に対する上部構造物と免震層の最大 変位応答はそれぞれ, $0.13 \mathrm{~cm}, 0.26 \mathrm{~cm}, 0.39 \mathrm{~cm}$ と $8.9 \mathrm{~cm}, 17.8 \mathrm{~cm}, 26.7 \mathrm{~cm}$ となる。すなわち， $f_{\max }$ を 整数倍すれば，最大層間変位応答も整数倍となる。これ は，本論で履歴特性を $p-d$ 特性としたことによるもの であって, 他の種類の履歴特性については検討が必要で ある。図一6より， $f_{g}$ が増加するにつれて，上部構造物 の応答は急激に減少する傾向を示し, 免震効果も顕著で ある。

粘塑性免震機構の持つ応答の低減効果は, 履歴減衰と 線形粘性減衰の両者によってもたらされる。そこで, 応 答の低減効果に及ぼす 2 種類の減衰（履歴减衰と線形粘
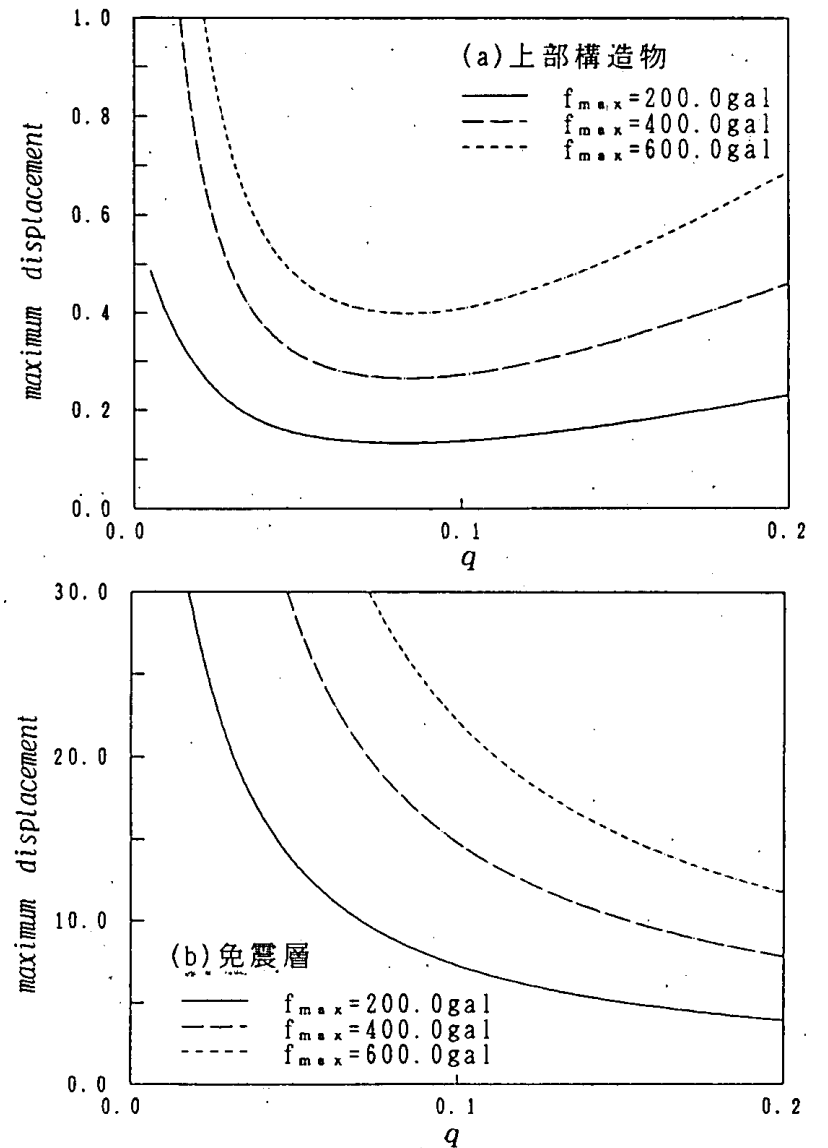

図一5 免震層の降伏加速度比に対する最大層間変位応答（粘塑 性免震系)
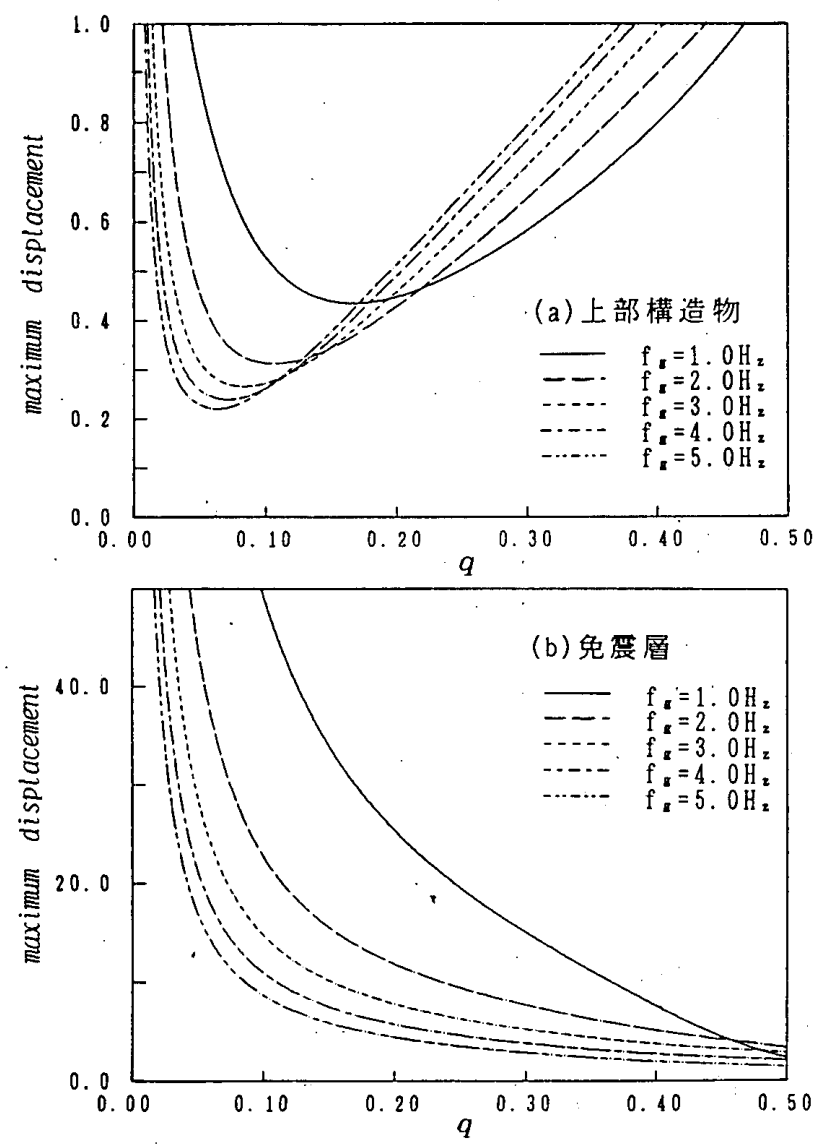

図一6 免震層の降伏加速度比に対する最大層間変位応答（粘塑 性免震系) 

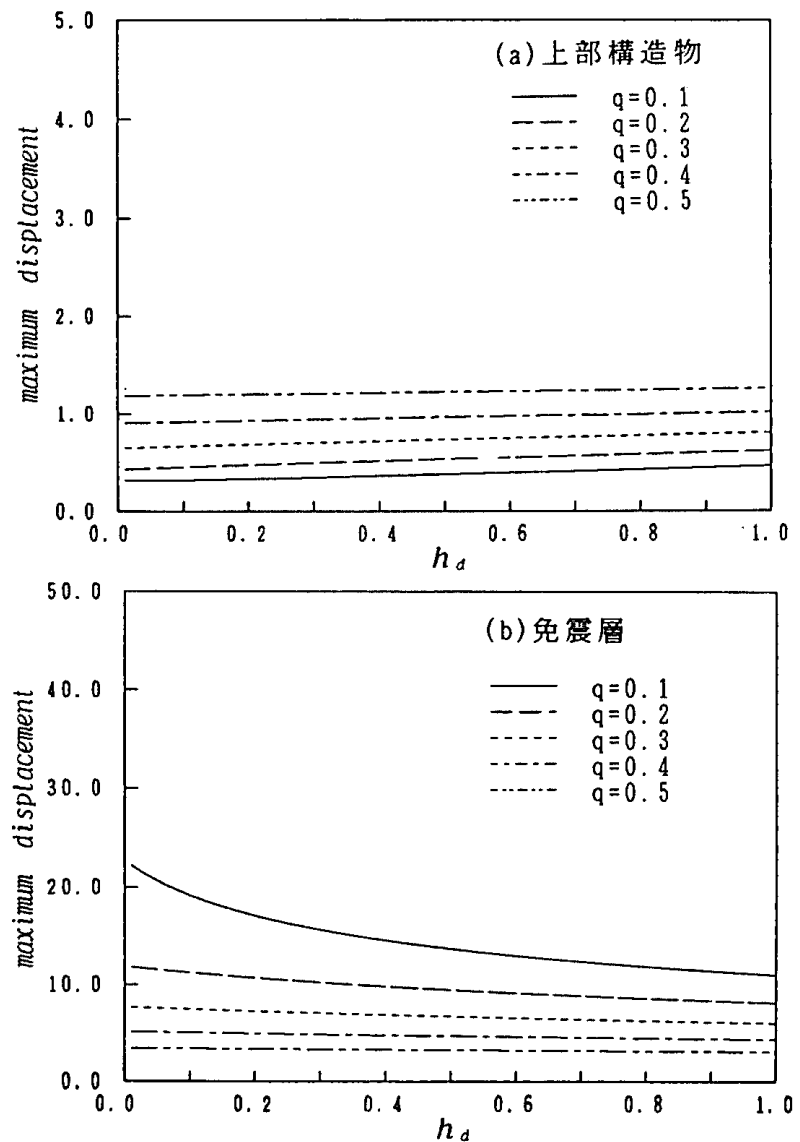

図一7免震層の臨界诚衰比に対する最大層間変位忘答（粘塑性 免震系)
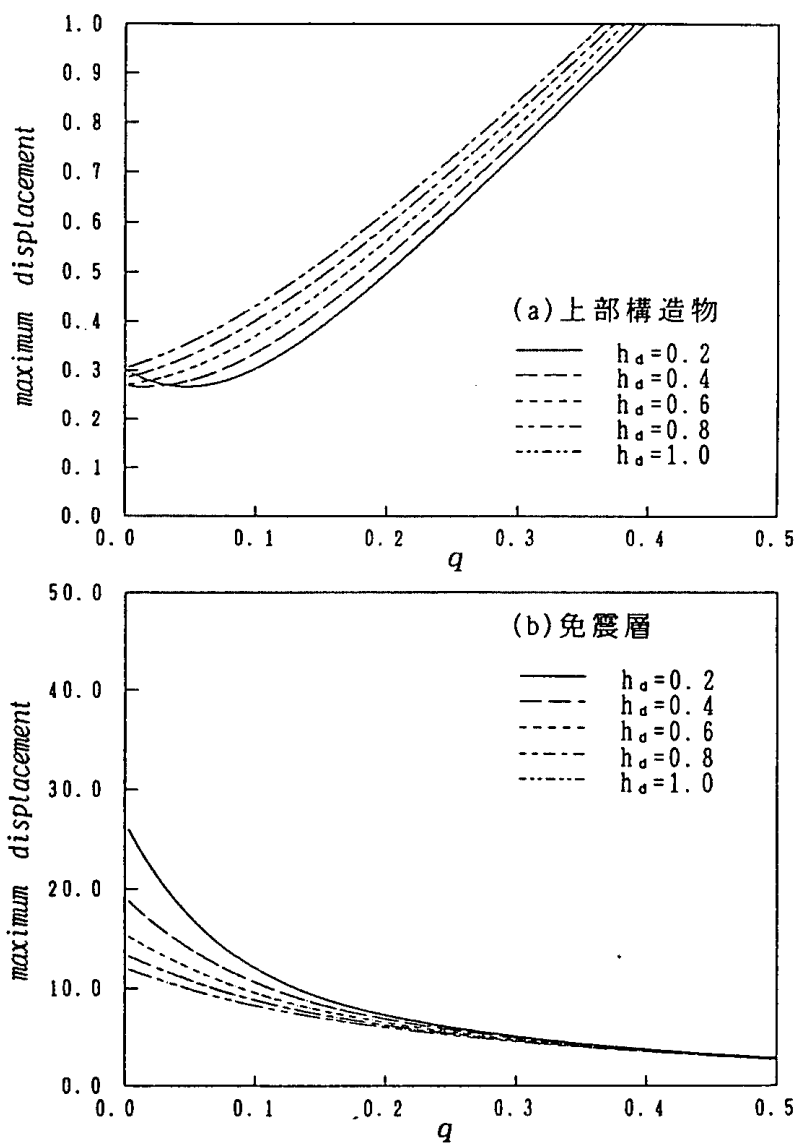

図一8 免震層の降伏加速度比に対する最大層間変位応答（粘塑 性免震系)
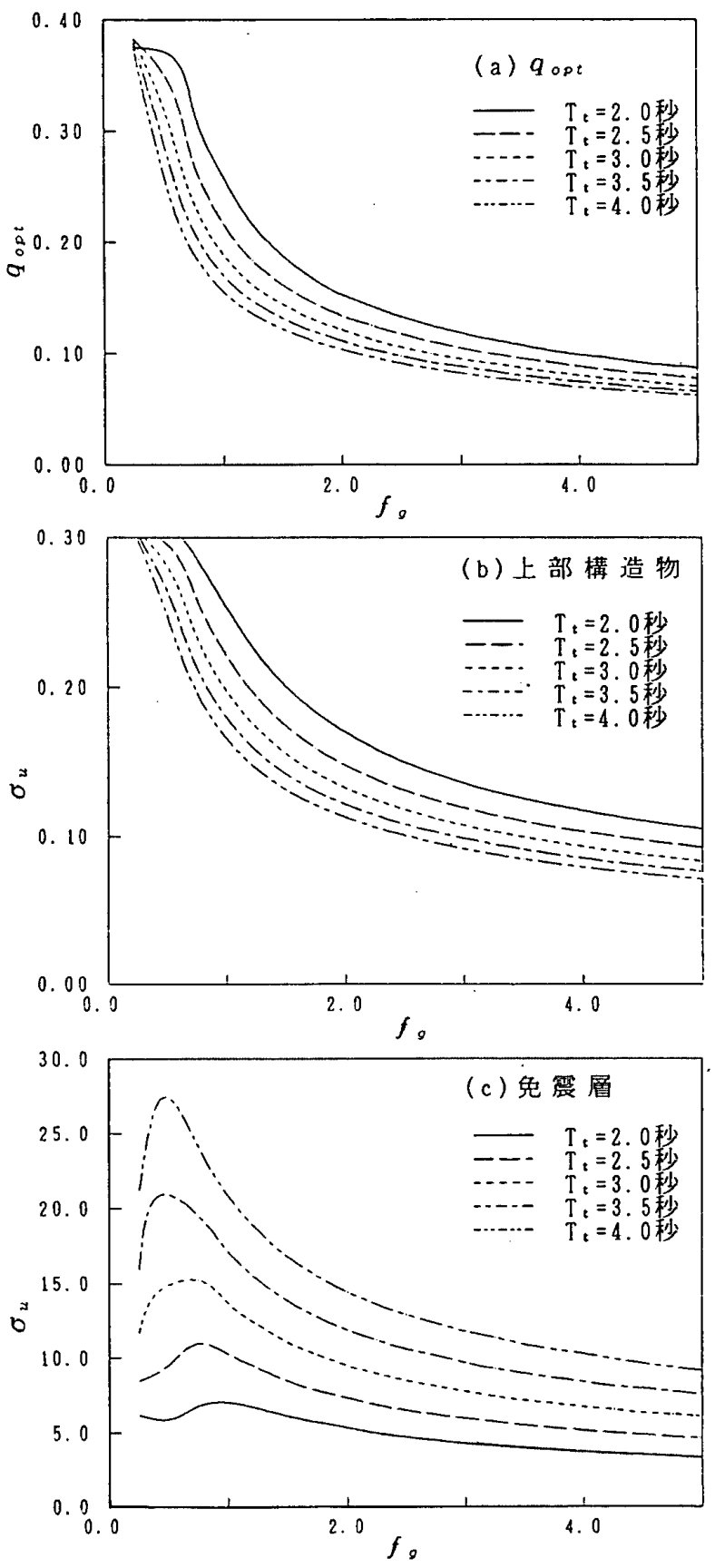

図一9上部構造物の統計的 2 次モーメント応答が最小となる地 震動の卓越振動数に対する各種応答

性減衰）の影響を明確にするために，図一7には， $h_{d}$ をパラメータにとり $q$ に対する上部構造物および，免 震層の最大層間変位応答が描加れている。図一8には, $q$ をパラメータにとり， $h_{d}$ に対する結果が示されてい る。図一7,8より， $h_{a}$ が増加するに伴い免震層の層間 変位応答は減少し上部構造物の応答は増加し, $q$ が増加 するに伴い，免震層亡上部構造物の応答は減少する。図 $-8(\mathrm{a})$ より, $h_{\alpha}=0.2$ の場合は, 上部構造物の最大変 位応答が最小となる $q_{o p t}$ が存在するが, $h_{d} \geqq 0.4$ では, 上部構造物の応答は $q$ が増加するにともなって, 単調 に增加する傾向を示す。図一 8 より， $h_{d}$ が増加するに ともなって, 上部構造物の応答は単調に增加し, 免震層 
の応答は，単調に減少する傾向を示す。また, $q$ が増加 すると $h_{\alpha}$ に対する免震層と上部構造物の最大変位応答 は緩やかに変化する傾向を示す。これらのことから，免 震効果は, 強い履歴をもつ場合, 線形粘性減衰に依存し なくなる傾向があり，履歴减衰の影響が支配的であると 考えられる。

免震系の最適動力学パラメーター $\left(q_{\text {opt }}\right)$ およびそれに 対応する上部構造物および免震層の応答と系の特性との 関係を明確に示すために，図一9には，2.5 節 (13) 式 の制御変数に関する偏微分が零となる $q_{\text {opt }}$ および，上 部構造物と免震層の 2 次モーメント応答が， $f_{g}$ に対し て $T_{t}$ をパラメータに選び描かれている。 $f_{g}$ が大きくな るに伴い，同図（a）では， $q_{\text {opt }}$ は城少し，同図 (b) で は, 上部構造物の忘答が低減され，免震効果がよく現れ ており, 同図 (c) では, 免震層の店答は， $f_{g}<1$ で最 大值を持ち， $f_{g} \geqq 1$ で応答は娍少する傾向がある。この ことより，当然ながら卓越振動数が免震建物の固有振動 数に近いほど各種応答量は大きくなることがわかる。こ の現象を抑制するために，粘弾性免震機構は，大きな履 歴消費エネルギーを必要とする。

3.4 確率統計的非定常地震入力による検討の一例 前節までの確率統計的定常地震入力に対する結果の妥 当性の検討のために，非定常入力について検討した一例 を以下に示す。

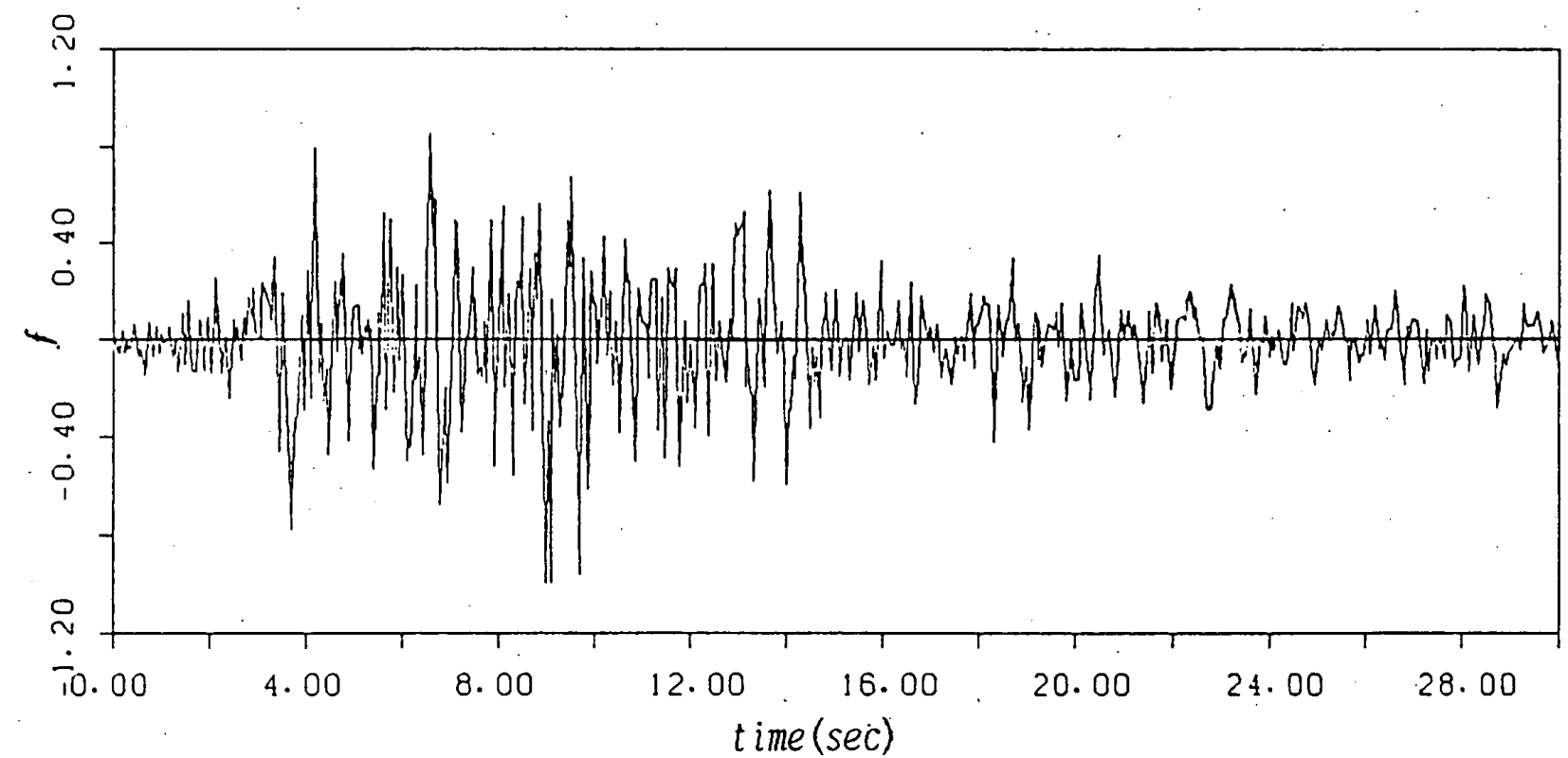

(a) 実測記録波形

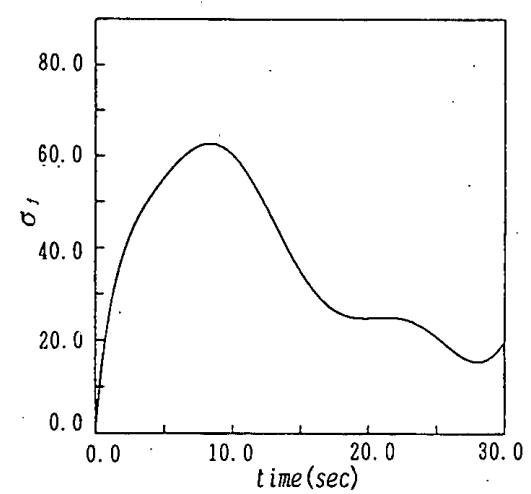

(b) 振幅包絡線関数

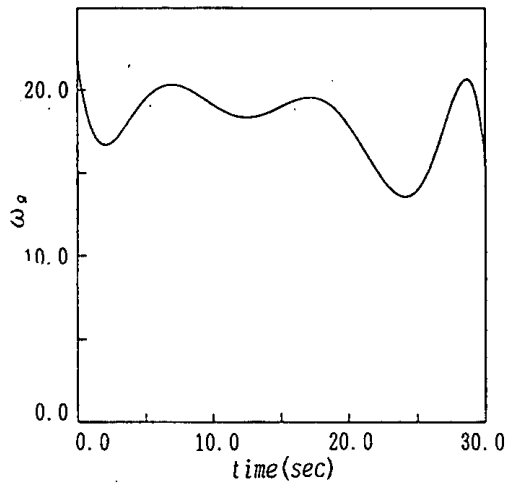

(c) 卓越振動数

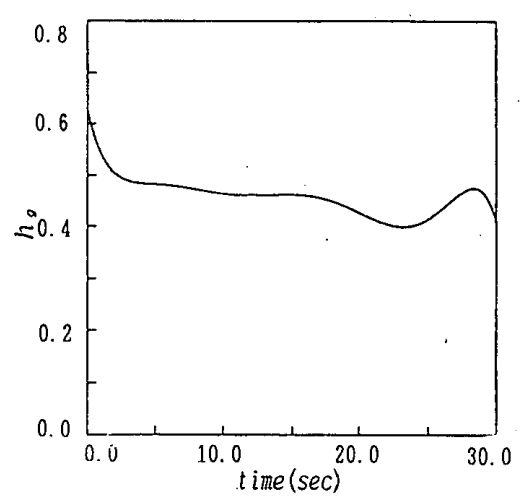

(d) 形状係数

図一10 入力地震動（Taft 地震）

図一10には1958 年の Karn County 地震時に Taft で 観測された実測地震波（以降 Taft 地震と記す）の（a） 加速度波形をもとにして得られた入力地動加速度の（b) R. M. S. 值 $\left(\sigma_{f}\right)$, (c) 卓越振動数 $\left(\omega_{g}\right)$, (d) 形状係数 $\left(h_{g}\right)$ を示す5)。図一11 は, 最大加速度レベルを $200 \mathrm{gal}$ とした場合の粘弾性免震構造物モデルの（a）上部構造 物之（b）免震層の層間変位応答の非定常 R.M.S. 值が $h_{a}$ をパラメータに選び描かれている。また, 図一12は, 最大加速度レベルを $400 \mathrm{gal}$ とした場合の粘塑性免震構 造物モデルに関する同様の結果が $q$ をパラメータに選 び描かれている。図-11 から，上部構造物と免震層の 応答は, 免震層の臨界減衰比を定常入力に基づく最適値 


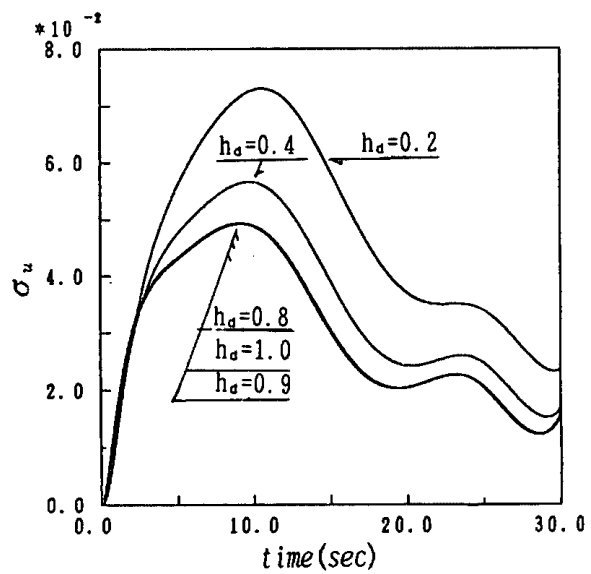

(a) 上部構造物

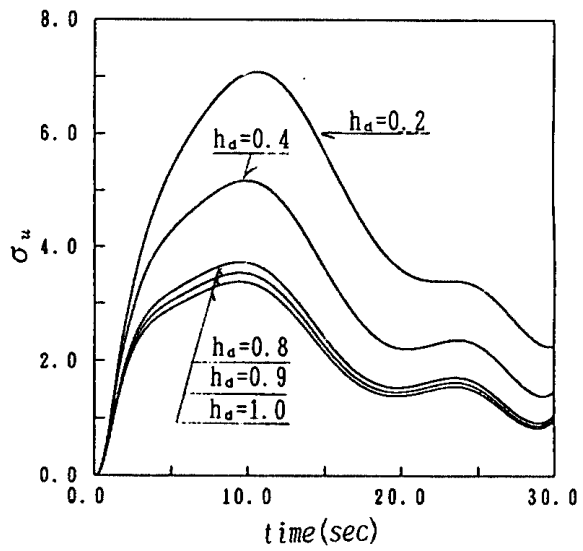

（b）免震層

图一11 時刻歴応答（粘弹性免震機構）

$h_{\text {opt }} \simeq 0.9$ とした場合が全継続時間にわたって最もよく 低減され，免震効果が顕著であることが分かる。また， 図一12 から, 上部構造物の応答も定常入力に基づく最 適降伏加速度比近傍の值で, 全継続時間にわたって最も よく低減されている。

\section{4. 結 び}

本論では, ホワイトノイズ過程を受ける 1 質点系で表 される表層地盤モデルの絶対加速度応答の 2 乗平均值, 卓越振動数およびパワースペクトルの形状係数により規 定されるノンホワイトノイズ過程を地震入力モデルと し，線形粘弾性および履歴特性として p.d. 特性を持つ 免震系のランダム応答解析法を開発した。免震系の最適 動力学パラメーターが，2次モーメント応答を使った極 值問題の解として得られることを示し，2 質点免震系に ついて数值解析例を示した。

解析の結果, 線形粘性減衰型のダンパーの最適臨界減 衰比並びに履歴減衰型ダンパーの p.d. 特性の最適降伏 特性值については，確定入力による従来の結論に特に新 しい知見を加えることはできていない。しかしながら， 本論のねらいは，免震系の基本応答特性に加えてその最 適パラメーター評価に確定入力とは違った形のアプロー

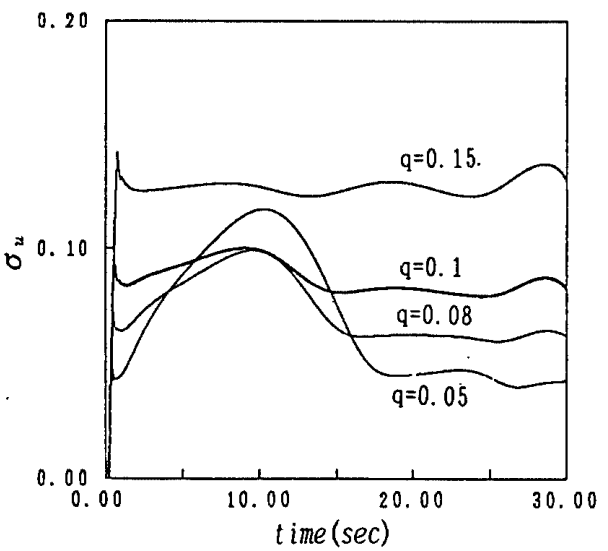

(a) 上部構造物

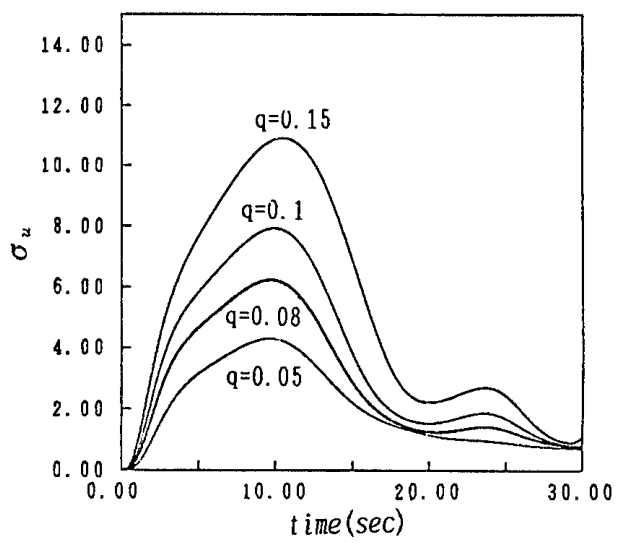

(b) 免震層

図一12 時刻歴応答（粘塑性免震機構）

チを示し，その解析例を示すことにあり，バイリニヤ型 履歴免霞系を含む各種の履歴免震系の基本応答特性とそ の最適パラメータについて検討することが可能であっ て，それらについては稿を改韩告する予定である。

\section{謝 辞}

本論の図面作成にご協力頂いた関西大学大学院生・ 中川肇君に厚く感謝の意を表します。

\section{参考文献}

1）浅野幸一郎, 津田憲昭：弾性構造物の最適地震信頼性設 計, 日本建築学会構造系論文報告集, 第 431 号, pp. 33 $\sim 36,1992$ 年 1 月

2）日本建築学会：免震構造設計指針，1989 年 9 月

3）小堀錊二, 南井良一郎, 浅野幸一郎: 履歴塑性変形領域 における 1 質点構造物の定常ランダム応答について, 日 本建築学会構造系論文報告集, 第 226 号, pp. $29 \sim 37$, 1974 年 12 月

4）浅野幸一郎：地震入力パラメータの変動を考慮した構造 物の動的応答, 日本建築学会構造系論文報告集, 第 400 号, pp. $123 \sim 130,1989$ 年 6 月

5）浅野幸一郎：地震入力を受ける履歴構造物の信頼性，日 本建築学会構造系論文報告集, 第 357 号, pp. 38 43, 1985 年 11 月

(1992 年 2 月 24 日原稿受理, 1992 年 6 月 26 日採用决定) 